\title{
Microbial-Induced Calcite Precipitation
}

Contributors: , Md Rajibul Karim ${ }^{1}$, Md Mizanur Rahman 2 , Isaac Ahenkorah ${ }^{3}$ , Asif Iqbal 4

1, Geotechnical Engineering, University of South Australia, UniSA STEM, Mawson Lakes, SA 5095, Australia; rajibul.karim@unisa.edu.au

2, Associate Professor, Geotechnical Engineering, University of South Australia, UniSA STEM, Mawson Lakes, SA 5095, Australia; mizanur.rahman@unisa.edu.au

3, PhD candidate, Geotechnical Engineering, University of South Australia, UniSA STEM, Mawson Lakes, SA 5095, Australia; isaac.ahenkorah@mymail.unisa.edu.au

4, Research Associate, University of South Australia, UniSA STEM, Mawson Lakes, SA 5095, Australia; asif.iqbal@unisa.edu.au

Version received: 5 August 2020

check for updates

\section{Definition}

Microbial-induced calcite precipitation (MICP) is a process that uses naturally occurring bacteria to bind soil particles together through calcium carbonate $\left(\mathrm{CaCO}_{3}\right)$ precipitation. It is a promising new technology in the area of Civil Engineering with the potential to become a cost-effective, environmentally friendly, and sustainable solution to many problems such as ground improvement, liquefaction remediation, enhancing properties of concrete, and so forth.

Table of Contents [Hide]

\section{Definition}

Microbial-induced calcite precipitation (MICP) is a process that uses naturally occurring bacteria to bind soil particles together through calcium carbonate $\left(\mathrm{CaCO}_{3}\right)$ precipitation. It is a promising new technology in the area of Civil Engineering with the potential to become a cost-effective, environmentally friendly, and sustainable solution to many problems such as ground improvement, liquefaction remediation, enhancing properties of concrete, and so forth.

\section{Introduction}

With increasing population and civil infrastructure demands worldwide, the availability of suitable soil sites for construction continues to decrease and ground improvement is now an integral part of many modern development projects. The most common methods to strengthen soils use either one or a combination of several mechanisms such as compaction, preloading, vibration, and chemical grouting. These techniques have been proven to have different degrees of effectiveness in improving soil strength and other properties in different situations. However, they come at a cost of consumption of a substantial amount of energy either in their application or production of the grouting materials or both.

Microbial-induced calcite precipitation (MICP) uses naturally occurring bacteria to bind soil particles together through calcium carbonate $\left(\mathrm{CaCO}_{3}\right)$ precipitation as shown in Figure 1, thereby increasing the strength. The expected life of MICP-treated soil is more than 50 years, which is compatible with the expected service life of many geotechnical structures [1]. Therefore, biogeochemical processes in MICP offer the potential for solving many engineering issues related to ground improvement. MICP also offers advantages over other common approaches as it uses natural processes and it has the potential of being a comparatively inexpensive technique. 
The effectiveness of MICP in cementing soil depends on the types of biogeochemical process chosen, type of bacteria used, their concentration, the $\mathrm{pH}$ and temperature, the concentration and volume of cementation solution, the soil properties (e.g., the availability of nucleation sites, degree of saturation, soil gradation, particle size, pore throat size) and so forth [2-6]. It is noteworthy to report that there are several review articles published in the past focusing on a particular aspect of MICP, e.g., optimizing protocols [7], mitigating liquefaction [8, 9], stabilization [7, 9-11], construction [12] and other aspects [13-20].

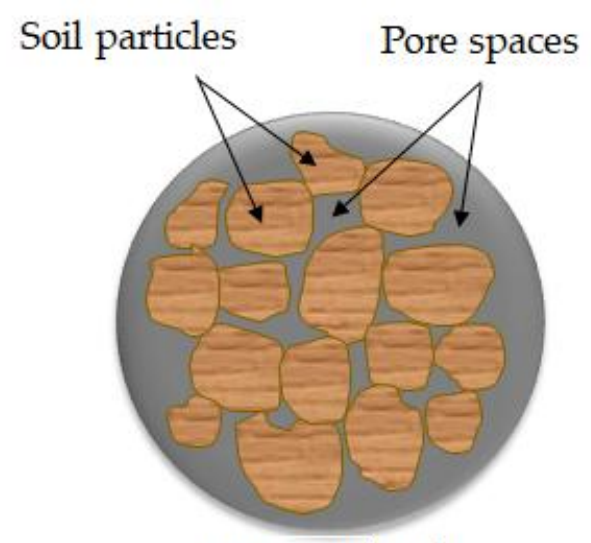

Untreated soil

\section{Biogeochemical process}

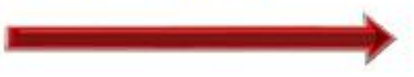

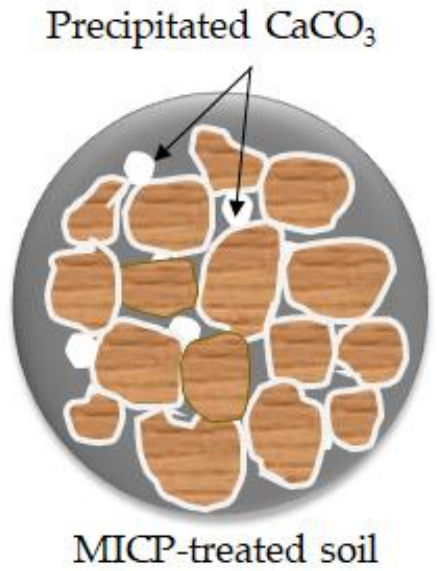

Figure 1. A schematic diagram of $\mathrm{CaCO}_{3}$ precipitation in the pore space of the soil matrix via MICP.

\section{Biogeochemical Processes}

As discussed before, the effectiveness of the MICP process depends on several physical and biogeochemical factors. These factors are carefully reviewed and discussed below.

\subsection{Bacteria Used in MICP}

The most commonly used urease bacteria in past studies are S. pasteurii, Spoloactobacilus, Clostridium, and Desulfotomaculum. Of these, S. pasteurii, an alkalophilic non-pathogenic bacterium with highly active urease enzymes, has been found to be one of the most effective and efficient and has been widely used [5, 21-24] even though contradictory evidence can be found in the literature [25, 26].

Venda Oliveira et al. [27] assessed the performances of two types of bacteria (S. pasteurii and $I$. insulisalsae) on the strength and stiffness of sandy soil using UCS and splitting tensile strength (STS) tests. The results from their study show that the bacterium I. insulisalsae was more efficient than $S$. pasteurii in strengthening the soil. However, the optimum environmental conditions for the growth of each bacterium was not considered in their study, which could have affected their findings.

The screening of bacteria for self-healing of concrete cracks was investigated by Zhang et al. [28]. In their study, the calcium precipitation activity (CPA) of bacterial strains was evaluated using genomic $16 \mathrm{~S}$ rDNA sequencing and phylogenetic tree analysis. The results from their study show that the Bacillus species (which was designated as the $\mathrm{H} 4$ strain) showed the highest CPA of $94.8 \%$. By assessing the influence of other factors on the performance of the $\mathrm{H} 4$ strain, they observed that lactate and nitrate were the best carbon and nitrogen sources for the $\mathrm{H} 4$ bacterial strain, with optimal concentrations of approximately 25 and $18 \mathrm{mM}$, respectively, at an optimum $\mathrm{pH}$ range of 9.5-11.0.

\subsection{Biogeochemical Mechanisms in MICP}

Biological processes involved in MICP can be broadly categorized into two groups, i.e., biostimulation and bioaugmentation. In biostimulation, indigenous microbes of the soil are stimulated with external nutrient medium, thereby inducing growth. Bioaugmentation occurs when external microbes are either injected or percolated into the soil along with nutrient medium to help their growth. 
Gomez et al. [29] assessed the performance of biostimulated treatment solutions to stimulate native ureolytic bacteria in a variety of soils using soil columns $(10.2 \mathrm{~cm}$ height $\times 5.1 \mathrm{~cm}$ diameter). The results from their study showed strength improvement and a significant reduction in the permeability of the treated soils. A maximum UCS of 5.3 MPa with an average calcite content of $13.2 \%$ was achieved in their study. A large-scale biostimulation experiment was conducted by Gomez et al. [30] using two identical $1.7 \mathrm{~m}$ diameter and $0.3 \mathrm{~m}$ thick soil layers in a tank. Cone penetration tests were conducted after treatment and they observed that biostimulation may provide good cementation improvement at that scale. Chen and Achal [31] demonstrated that a biostimulation process can be used to precipitate calcite inside a soil matrix and at the same time can effectively remediate Cu contamination by precipitating carbonates of $\mathrm{Cu}$. Feng and Achal [32] used a small quantity of cement and biostimulation to improve the strength of rammed earth materials. Despite the success of implementing the biostimulation approach in some studies, this approach has its drawbacks, such as homogeneity of treatment and a longer time requirement for the stimulation and growth of microbes.

The MICP process can be achieved through many biogeochemical pathways including urea hydrolysis, denitrification, iron reduction, sulphate reduction and others [24-26]. Among these, urea hydrolysis has been most widely used due to its high $\mathrm{CaCO}_{3}$ precipitation efficiency. On the other hand, denitrification, iron reduction and sulphate reduction have been paid less attention due to the low solubility of oxidizing substrates and as a result, require a large amount of substrate solution to obtain sufficient precipitation [33].

In urea hydrolysis, the major ingredients involved are urease enzyme, urea $\mathrm{CO}\left(\mathrm{NH}_{2}\right)_{2}$ and calcium chloride $\mathrm{CaCl}_{2}$. In general, $\mathrm{CaCO}_{3}$ precipitation via urea hydrolysis can be divided into three main stages: (1) hydrolysis of urea into ammonium $\left(\mathrm{NH}_{4}{ }^{+}\right)$and carbonate ions $\left(\mathrm{CO}_{3}{ }^{2-}\right)$; (2) dissociation of $\mathrm{CaCl} 2$ into calcium ions $\left(\mathrm{Ca}^{2+}\right)$; and (3) $\mathrm{CaCO}_{3}$ precipitation. The chemical reactions involved are presented in Equations 1 to 3 .

$$
\begin{gathered}
\mathrm{CO}\left(\mathrm{NH}_{2}\right)_{2}+2 \mathrm{H}_{2} \mathrm{O} \stackrel{\text { urea-hydrolysis }}{\rightarrow} 2 \mathrm{NH}_{4}^{+}+\mathrm{CO}_{3}^{2-} \\
\mathrm{CaCl}_{2} \stackrel{\mathrm{H}_{2} \mathrm{O}}{\rightarrow} \mathrm{Ca}^{2+}+2 \mathrm{Cl}^{-} \\
\mathrm{Ca}^{2+}+\mathrm{CO}_{3}^{2-} \stackrel{\text { precipitation }}{\rightarrow} \mathrm{CaCO}_{3}
\end{gathered}
$$

Compared to other microbial pathways, $\mathrm{CaCO}_{3}$ precipitation via urea hydrolysis provides many advantages including a high chemical conversion efficiency up to $90 \%$ and ease of control of the process. A disadvantage of this process can be the release of undesirable $\mathrm{NH}_{4}{ }^{+}$and can be treated as a major cause of water pollution and potent oxygen demand [26].

MICP by denitrification refers to dissimilatory reduction of nitrate $\left(\mathrm{NO}_{3}{ }^{-}\right)$to generate nitrogen gas $\left(\mathrm{N}_{2}\right)$, inorganic carbon $\left(\mathrm{CO}_{2}\right)$, and alkalinity $\left(\mathrm{OH}^{-}\right)$using denitrifying bacteria (e.g., Pseudomonas denitrificans) under anaerobic conditions. The generation of $\mathrm{CO}_{2}$ raises the carbonate content of the solution, while the consumption of $\mathrm{NO}_{3}{ }^{-}$increases the $\mathrm{pH}$. The production of alkalinity favours precipitation of $\mathrm{CaCO}_{3}$ in the presence of $\mathrm{Ca}^{2+}$. The chemical reactions are presented in Equations 4 and 5.

$$
\begin{gathered}
\mathrm{NO}_{3}^{-}+1.25 \mathrm{CH}_{2} \mathrm{O} \stackrel{\text { denitrification }}{\rightarrow} 0.5 \mathrm{~N}_{2}+1.25 \mathrm{CO}_{2}+0.75 \mathrm{H}_{2} \mathrm{O}+\mathrm{OH}^{-} \\
\mathrm{Ca}^{2-\uparrow}+\mathrm{CO}_{2}+2 \mathrm{OH}^{-} \stackrel{\text { precipitation }}{\rightarrow} \mathrm{CaCO}_{3}+\mathrm{H}_{2} \mathrm{O}
\end{gathered}
$$

Compared to urea hydrolysis, denitrification requires a lower concentration of the substrate to induce $\mathrm{CaCO}_{3}$ precipitation, however, the rate of $\mathrm{CaCO}_{3}$ precipitation is considerably lower, possibly due to the accumulation of intermediate $\mathrm{NO}_{3}{ }^{-}$. A high initial $\mathrm{NO}_{3}{ }^{-}$concentration may inhibit bacteria growth by altering the $\mathrm{pH}$ across the cell membrane. 
In MICP by sulphate reduction (similar to iron reduction), sulphate-reducing bacteria (e.g., Desulfovibrio and Desulfotomaculum) oxidize sulphates under anaerobic conditions to produce hydrogen sulphide $\left(\mathrm{H}_{2} \mathrm{~S}\right), \mathrm{CO}_{2}$ and increased alkalinity. $\mathrm{pH}$ due to increased alkalinity favours $\mathrm{CaCO}_{3}$ precipitation. The sulphate reduction process is presented in Equation 6.

$$
\mathrm{SO}_{4}^{2-}+2 \mathrm{CH}_{2} \mathrm{O} \stackrel{\text { sulphate-reduction }}{\rightarrow} \mathrm{H}_{2} \mathrm{~S}+2 \mathrm{CO}_{2}+2 \mathrm{OH}^{-}
$$

The release of $\mathrm{CO}_{2}$ in the presence of $\mathrm{Ca}^{2+}$ fosters $\mathrm{CaCO}_{3}$ precipitation (see Equation 5). Anaerobic oxidation via sulphate reduction requires a large substrate quantity due to low solubility. The mechanism also results in the production of $\mathrm{H}_{2} \mathrm{~S}$, which is an odorous and highly toxic gas even at low concentrations.

\section{Engineering Properties of Treated Soil}

The calcite precipitation modifies or enhances the strength of the sample and different studies have investigated this influence through various laboratory tests namely, UCS tests [24, 34-39], STS tests [27, $37,38,40-43]$, direct simple shear tests [44], triaxial tests [21, 37, 45-50], cyclic triaxial tests [51] and cone penetration tests [52]. Some of the observations are summarised below.

\subsection{Unconfined Compressive Strength}

Several studies conducted UCS tests on many different types of MICP-treated soil to quantify the improvement of strength. A summary of the studies is presented in Table 2. A brief overview of the literature is presented below.

Table 2. Summary of studies using UCS tests to evaluate strength improvement in MICP-treated soils.

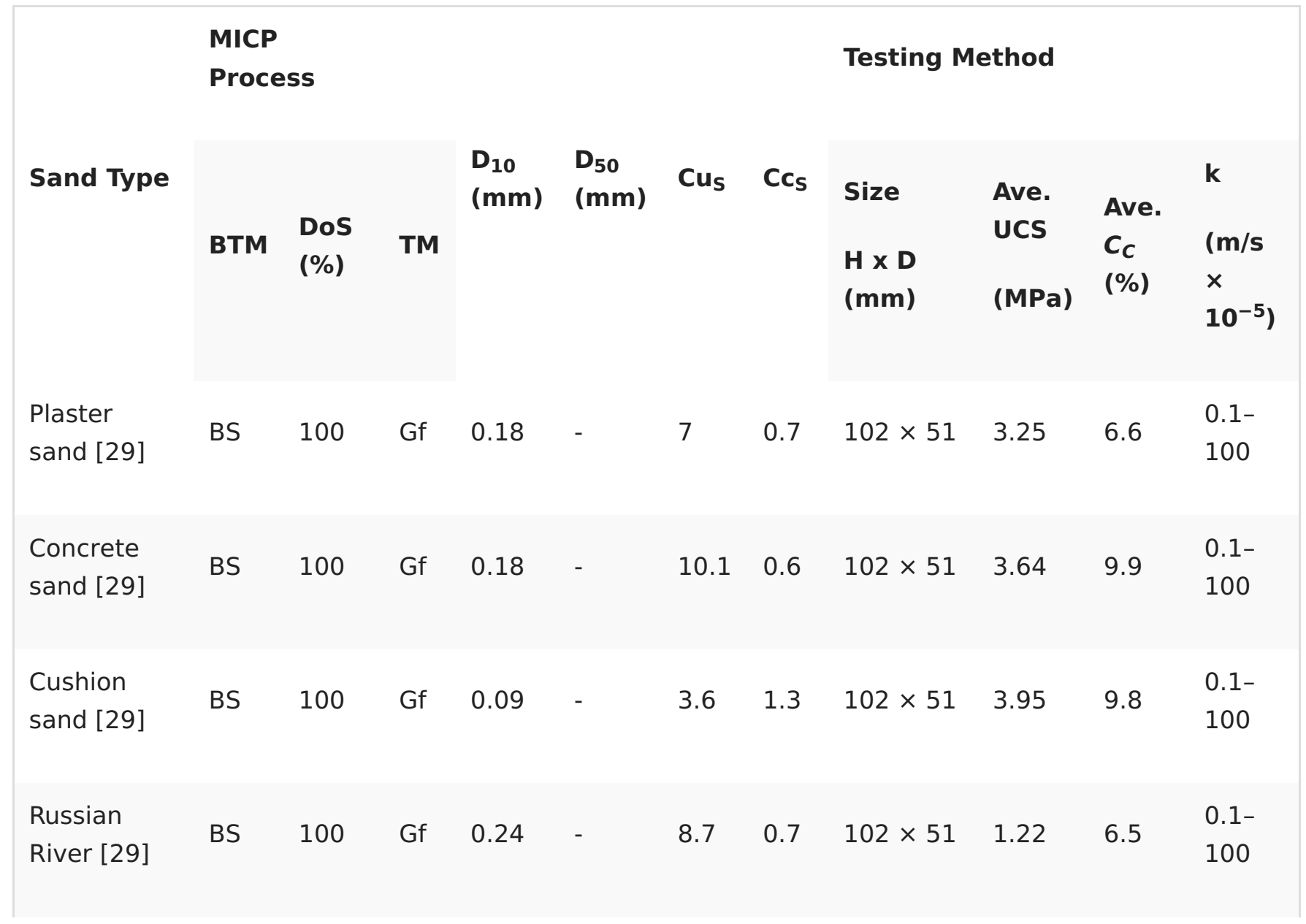




\begin{tabular}{|c|c|c|c|c|c|c|c|c|c|c|c|}
\hline $\begin{array}{l}\text { Folsom Lake } \\
\text { [29] }\end{array}$ & BS & 100 & Gf & 0.24 & - & 6.9 & 0.7 & $102 \times 51$ & 1.07 & 7.4 & $\begin{array}{l}0.1- \\
100\end{array}$ \\
\hline $\begin{array}{l}\text { Napa Bay } \\
\text { [29] }\end{array}$ & BS & 100 & Gf & 0.18 & - & 1.6 & 0.8 & $102 \times 51$ & 5.34 & 13.2 & $\begin{array}{l}0.1- \\
100\end{array}$ \\
\hline $\begin{array}{l}\text { Cemex Fill } \\
\text { [29] }\end{array}$ & BS & 100 & Gf & 0.38 & - & 8.4 & 1.2 & $102 \times 51$ & 2.67 & 6.0 & $\begin{array}{l}0.1- \\
100\end{array}$ \\
\hline $\begin{array}{l}\text { Granite } \\
\text { sand [29] }\end{array}$ & BS & 100 & Gf & 0.22 & - & 7.7 & 0.6 & $102 \times 51$ & 2.73 & 7.5 & $\begin{array}{l}0.1- \\
100\end{array}$ \\
\hline $\begin{array}{l}\text { Coarse } \\
\text { sand [36] }\end{array}$ & BA & $\begin{array}{l}30- \\
100\end{array}$ & I & 0.54 & 0.70 & 1.27 & 0.1 & $110 \times 55$ & $\begin{array}{l}0.1- \\
2.4\end{array}$ & $4-14$ & $\begin{array}{l}8.0- \\
42\end{array}$ \\
\hline $\begin{array}{l}\text { Silica sand } \\
\text { [35] }\end{array}$ & BA & 100 & I & 0.25 & - & - & - & $\begin{array}{l}1000 \times \\
45\end{array}$ & $9-20$ & - & - \\
\hline $\begin{array}{l}\text { Pure silica } \\
\text { sand [24] }\end{array}$ & BA & Unsat & SP & 0.23 & - & - & - & $\begin{array}{l}1000 \times \\
45\end{array}$ & 19.61 & - & - \\
\hline
\end{tabular}

Silica sand [39]

BA Unsat SP $\quad 0.35$

$2000 \times$
55 $\quad 0.065$

$\begin{array}{llllllllllll}\text { Ottawa } & \text { BA } & 100 & \text { Sb } & 0.19 & 0.30 & 1.8 & 1.1 & 102 \times 51 & 1.9-15 & 1.8- & - \\ \text { silica [34] } & & & & & & & & & 14 & \end{array}$

$\begin{array}{lllllllllllll}\text { Fine sand } & \text { BA } & 100 & \mathrm{I} & 0.10 & 0.19 & 2.1 & 0.9 & 100 \times 50 & 0.6- & 4-9 & - \\ {[53]} & & & & & \end{array}$

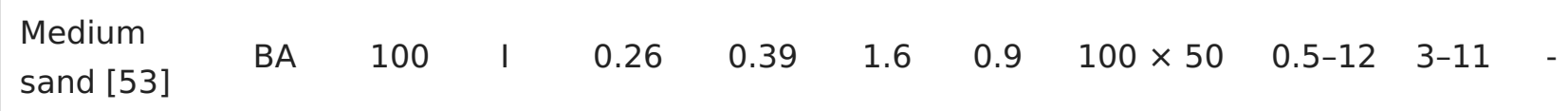

$\begin{array}{lllllllllllll}\begin{array}{l}\text { Coarse } \\ \text { sand [54] }\end{array} & \text { BA } & 100 & \text { I } & 1.45 & 1.60 & 1.4 & 1.0 & 102 \times 51 & 0.5-15 & 2-23 & - \\ & & & & & & & & & & & & \\ \text { Coarse } & \text { BA } & 100 & \text { SP } & 0.61 & 0.72 & 1.2 & 1.0 & 100 \times 50 & 0.2- & 3-16 & 0.1- \\ \text { sand [55] } & & & & & & & & & & & & \end{array}$

Ottawa 20-

30 [37]

BA $100 \quad$ I

0.72

$1.2 \quad 1.0 \quad 75 \times 25 \quad 2.5$

$6.5-$ 
Ottawa 50-

70 [37]

BA $100 \quad$ I

0.22

1.4

$0.975 \times 25$

3.04

10.8 -

Navada

[37]

BA $100 \quad$ I

0.12

1.7

1.2

$75 \times 25$

2.6

13.9 -

Ottawa 2030 [42]

BA $100 \quad$ I 0.65 -

$\begin{array}{llllll} & & 0.2- & & \\ 1.2 & 1.0 & 100 \times 50 & 1.8 & 8-12 & 6.0\end{array}$

Beach sand

[56]

BA $\quad 100 \quad$ I $\quad 0.50$

0.70

$100 \times 50$

$\begin{array}{ll}0.4-10 & 10- \\ 29\end{array}$

Ottawa 2030 [57]

BA $100 \quad$ I 0.65 -

$1.21 .0 \quad 100 \times 50$

0.8- 6.4-

4.0-

$1.1 \quad 7.6$

6.5

Mizunami

BS $100 \quad$ Gf -

$1.50 \quad-\quad-\quad 60 \times 30$

$\begin{array}{cl}0.9-10 & 10- \\ 32\end{array}$

sand [58]

Silica sand

[61]

BA $100 \quad$ I

$0.5-$

$1.2-\quad 0.9-$

$90 \times 45$

0.1- 1.4-

6.31 .1

$2.0 \quad 10$

Silica sand [59]

BA 100

$-\quad$ - $\quad 180 \times 50$

$0-\quad 1.0-\quad 4.0-$

0.31

$4.1 \quad 10$

Ottawa

sand [60]

BA 100 Gf -

$0.42 \quad-\quad$ - $\quad 100 \times 50$

$0.2-$

$5.2-\quad 0.1-$

sand [60]

14 soil

types [61]

$\begin{array}{llll} & & 0.07- \\ & 100 \quad I \quad & 0.38\end{array}$

2.3- 0.6-

$10.1 \quad 1.4$

$0.1-\quad 2.6-$

$5.4 \quad 14$

Standard

sand [62]

BA $100 \quad \mathrm{Sb}$ -

0.42

0.03- 1.4-

$2 \quad 10$

Residual

soil [63]

BA 100

$170 \times 50$

$0-0.2$

$0.6-$

2.8

Ottawa sand [34]

BA $\quad 100 \quad$ Sb $\quad 0.19$

0.30

$102 \times 51$

$0-2.3$

1.8
15

Itterbeck

fine [21]

BA $100 \quad$ -

$0.17 \quad 1.64$

$\begin{array}{ll}0.7-13 & \begin{array}{l}12- \\ 28\end{array}\end{array}$ 
Silica sand [64]

BA $100 \quad$ I -

$0.17 \quad-\quad-\quad 100 / 250$

$0-3.0$

2.610

BTM-Bio-treatment approach, BA-Bioaugmentation; BS-Biostimulation; DoS-Degree of Saturation; Dx-Particle size at ' $\mathrm{x}$ '\% finner; Cus-Uniformity coefficient of sand particles; Ccs-Coefficient of curvature of sand particles; TM-Treatment method; Gf_Gravity fed; I_Injection; Sb-Submerged; SPSurface Percolation; k-Soil permeability.

\subsection{Indirect (Splitting) Tensile Strength}

Similar to UCS, a series of STS tests on MICP-treated soils have been reported in recent literature [27, $37,38,40-43]$. In these studies, STS values have been assessed and compared with other parameters such as the $\mathrm{CaCO}_{3}$ content [37, 38, 40], different soil types [27, 40], and reinforced fibre content [4143]. A summary of the studies can be found in Table 3.

To evaluate the influence of different factors such as soil type, Cc and fibre content on the STS of MICPtreated soils, data from previous studies were compiled and critically analysed. The STS of MICP-treated soils ranges from 0.04 to $1.06 \mathrm{MPa}, C_{C}$ ranges from 3.8 to $31.0 \%$, while the fibre content ranges from 0 to $1.2 \%$. STS increases exponentially with increasing $C_{C}$; however, three distinct trends were observed possibly due to the effect of the particle size distribution not being properly captured by $D_{10}$ as well as the grain shape.

Table 3. A summary of the literature reporting STS test results on MICP-treated soils.

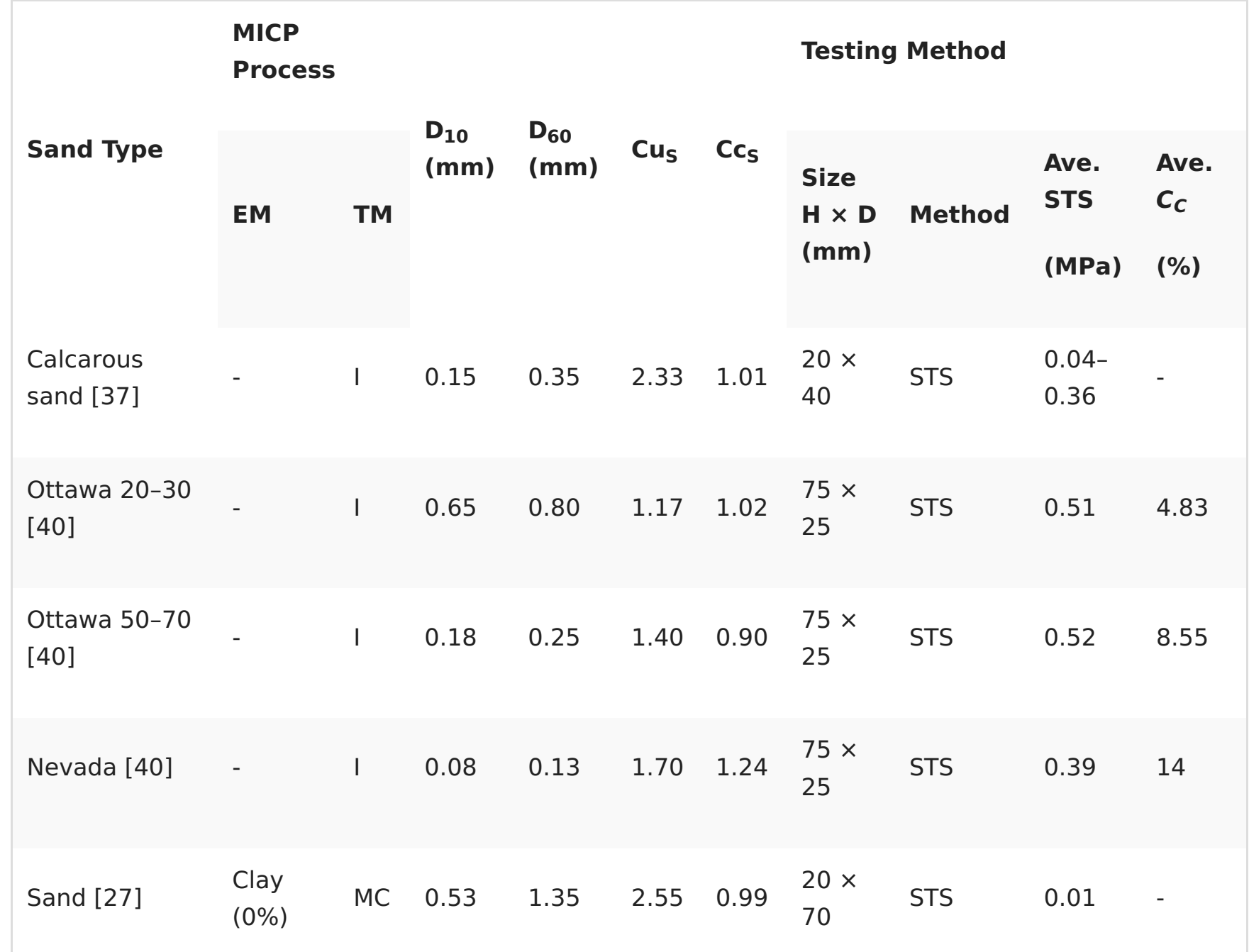




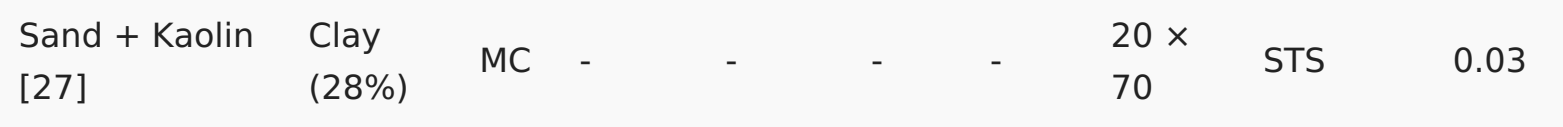

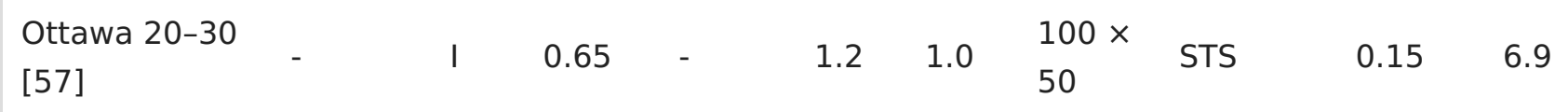

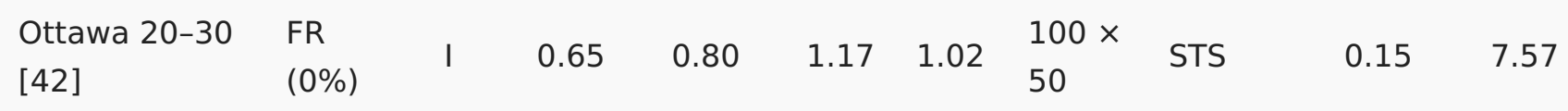

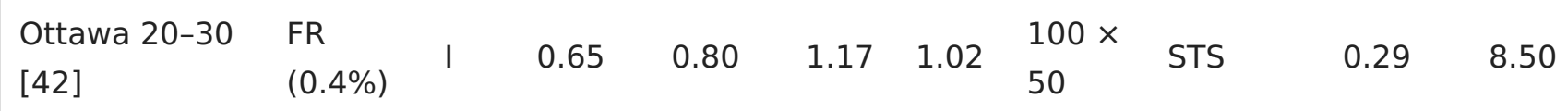

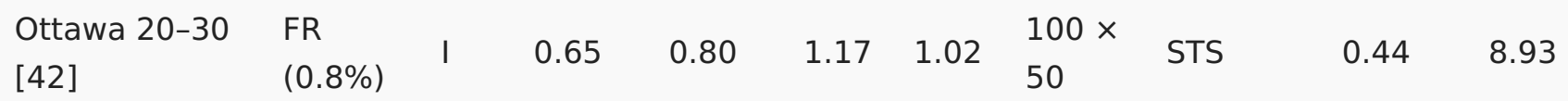

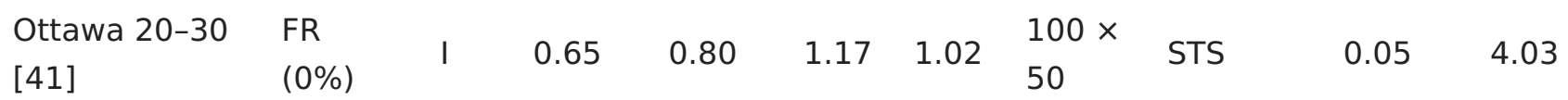

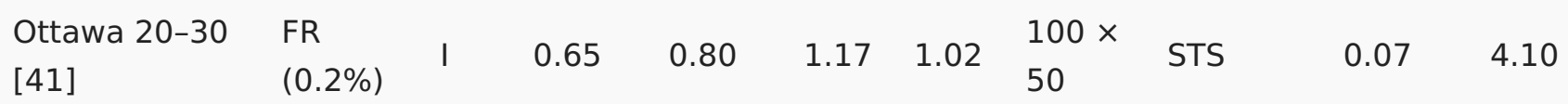

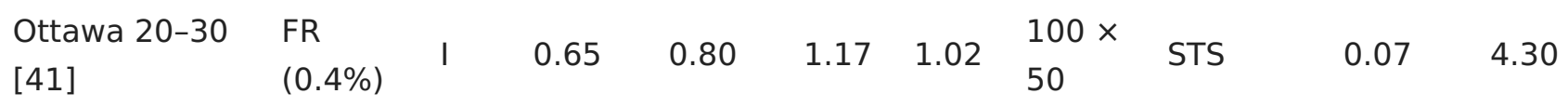

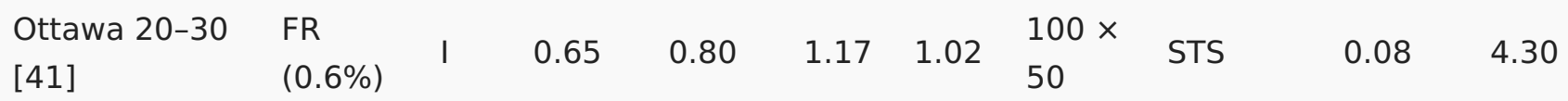

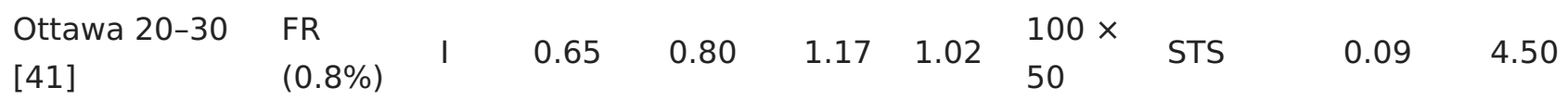

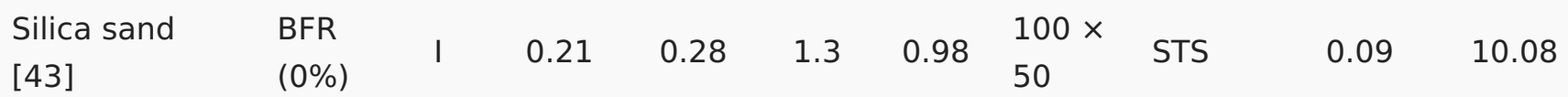

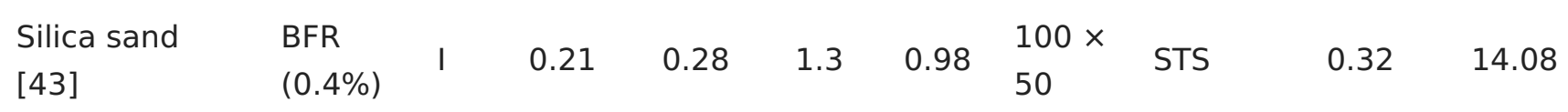

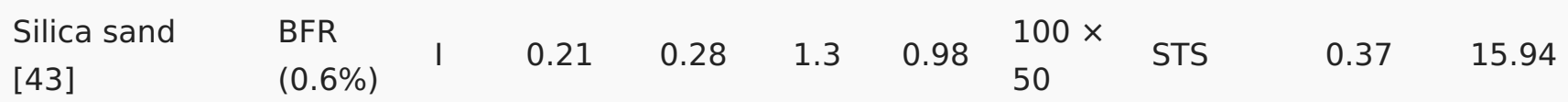

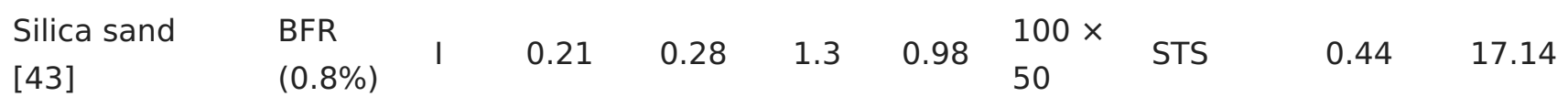




\begin{tabular}{|c|c|c|c|c|c|c|c|c|c|c|}
\hline $\begin{array}{l}\text { Silica sand } \\
\text { [43] }\end{array}$ & $\begin{array}{l}\text { BFR } \\
(1.0 \%)\end{array}$ & I & 0.21 & 0.28 & 1.3 & 0.98 & $\begin{array}{l}100 \times \\
50\end{array}$ & STS & 0.45 & 17.58 \\
\hline $\begin{array}{l}\text { Silica sand } \\
{[43]}\end{array}$ & $\begin{array}{l}\text { BFR } \\
(1.2 \%)\end{array}$ & I & 0.21 & 0.28 & 1.3 & 0.98 & $\begin{array}{l}100 \times \\
50\end{array}$ & STS & 0.33 & 14.87 \\
\hline
\end{tabular}

EM-Enhancement method; I-Injection; TM-Treatment method; FR-Fibre reinforcement; BFR-Basalt fibre reinforcement; $M C-$ Mixed and compacted; STS-Splitting tensile strength; $E_{50}^{\mathrm{S}}{ }_{50}$ secant elastic modulus at $50 \%$ of the peak tensile stress.

\section{Key Engineering Applications of MICP}

\subsection{MICP as Binders}

Le Métayer -Levrel et al. [65] suggested using the bacterial ability of MICP for producing superficial protective coatings for limestones buildings, monuments and statuary. Another study by Webster and May [66] also suggested bioremediation as an additional technology for restoring stone surfaces in heritage buildings.

MICP being a non-toxic and eco-friendly process has advantages over commonly used methods for binding soil particles, such as chemical grouting. Ivanov and Chu [67] evaluated the cost of raw materials for chemical grouting to be in the range of $\$ 2-\$ 72$ per $\mathrm{m}^{3}$ of soil whereas for microbial grouting was in the range of $\$ 0.5-\$ 9$ per $\mathrm{m}^{3}$ of soil when waste materials are used as a carbon source for microbial growth.

Ramachandran et al. [68] concluded through microscopy investigation that MICP is an effective method for crack remediation in concrete. Jonkers et al. [69] established that MICP is effective as a self-healing agent to activate the process of autonomous repair of freshly formed cracks. Achal et al. [70] suggested MICP as an alternative high-quality concrete sealant and crack remediation method which demonstrated a $36 \%$ increase in compressive strength of cement mortar as well as six times lower water absorption in the treated samples. Amidi and Wang [71] proposed a new surface treatment method for treating concrete and similar absorbent materials to enhance their resilience and mechanical properties and achieved a $36 \%$ increase in compressive strength due to MICP.

\subsection{Soil Strengthening and Stabilisation}

Multiple studies have applied MICP to different types of soil and tested these under various conditions for strength enhancement and soil stability. Dejong et al. [3] applied MICP to improve the engineering properties of sands such as shear strength and stiffness. The results showed that the ultimate shear capacity and initial shear stiffness were both higher for treated samples compared to untreated loose specimens. Whiffin et al. [4] applied MICP successfully using a $5 \mathrm{~m}$ long sand column for ground improvement which was achieved with relatively low flow rates. This study also mentioned that balancing the rate of urea hydrolysis with the delivery of reactants aided in the uniform distribution of $\mathrm{CaCO}_{3}$.

A study by Harkes et al. [5] evaluated MICP as in situ soil strengthening technique in fine-grained sand. The study reported that for a homogenous distribution of bacteria in large sand bodies, a low ionic strength solution promoted bacterial transport over longer distances. Many researchers have evaluated the strength of biotreated sands and have demonstrated improved strength, increased stiffness, liquefaction resistance and enhanced dynamic properties of the treated specimens [44, 72, 45, 73].

\subsection{MICP in Bricks}


Bricks constitute a significant part of construction materials and are known for their durability and sustainability. However, bricks are also prone to deterioration over time due to the presence of voids and pores resulting in cracking. MICP has proved to be a novel method of treating these cracks or strengthening bricks [74]. Raut et al. [75] demonstrated MICP in bricks and studied the effect of the method on compressive strength and water absorption capacity. Bricks treated with MICP showed $83.9 \%$ improvement in compressive strength and 48.9\% lower water absorption capacity after 28 days as compared to the control specimen. Lambert and Randall [76] evaluated the process of MICP to produce bio-bricks using the urea from stabilized human urine. Results demonstrated higher compressive strength with an increase in the number of treatments with the highest compressive strength of $2.7 \mathrm{MPa}$.

\subsection{Remediation of Contaminants from the Environment}

Rapid industrial development poses a major threat in the form of heavy metals and other contaminants as a by-product of these industries which impacts our environment. In the past, conventional treatments were used to remove heavy metals from contaminated environments. However, these methods are ineffective, expensive and consume high amounts of chemicals and energy [77]. Therefore, alternative methods such as MICP are needed to effectively remove heavy metals without having much impact on the environment. Several researchers $[2,78,79]$ have reported the capability of MICP for heavy metal remediation in the environment.

\section{References}

1. Dejong, T.J.; Soga, K.; Ian, K.; Burns, S.; Paassen, I.A.V.; Qabany, A.A.; Aydilek, A.; Bang, S.S.; Burbank, M.; Caslake, I.F.; et al. Biogeochemical processes and geotechnical applications: progress, opportunities and challenges. Géotechnique 2013, 63, 287-301.

2. Hammes, F.; Van Hege, K.; Van De Wiele, T.; Vanderdeelen, J.; Siciliano, S.D.; Verstraete, W. Calcium removal from industrial wastewater by bio-catalytic CaCO3 precipitation. J. Chem. Technol. Biotechnol. 2003, 78, 670-677, doi:10.1002/jctb.840

3. Dejong, J.; Fritzges, M.B.; Nusslein, K. Microbially Induced Cementation to Control Sand Response to Undrained Shear. J. Geotech. Geoenvironmental Eng. 2006, 132, 1381-1392, doi:10.1061/(asce)1090-0241(2006)132:11(1381).

4. Whiffin, V.S.; Van Paassen, L.A.; Harkes, M.P. Microbial Carbonate Precipitation as a Soil Improvement Technique. Geomicrobiol. J. 2007, 24, 417-423, doi:10.1080/01490450701436505.

5. Harkes, M.P.; Van Paassen, L.A.; Booster, J.L.; Whiffin, V.S.; Van Loosdrecht, M.C.M. Fixation and distribution of bacterial activity in sand to induce carbonate precipitation for ground reinforcement. Ecol. Eng. 2010, 36, 112-117, doi:10.1016/j.ecoleng.2009.01.004.

6. Montoya, B.M.; Safavizadeh, S.; Gabr, M.A. Enhancement of Coal Ash Compressibility Parameters Using MicrobialInduced Carbonate Precipitation. J. Geotech. Geoenvironmental Eng. 2019, 145, 04019018, doi:10.1061/(asce)gt.1943-5606.0002036

7. Yu, T.; Souli, H.; Péchaud, Y.; Fleureau, J.-M. Optimizing protocols for microbial induced calcite precipitation (MICP) for soil improvement-a review. Eur. J. Environ. Civ. Eng. 2020, 1-16, doi:10.1080/19648189.2020.1755370

8. Uba M, Z.; Anuar, K.K.; Sadiq, A.M. Bio-desaturation and bio-sealing techniques for mitigation of soil liquefaction: a review. Haryati, Y., Zurairahetty, M.Y.N., Syahrizal, I.I., Jamaludin, N., Abdullah, M.H., Ahmad, I.S., Ismail, D.S.A., Sirat, Q.A.S., Anuar, U.H.M., Ed.; In Proceedings of the 12th International Civil Engineering Post Graduate Conference, Johor, Malaysia, 27-28 August 2018

9. Muhammed, A.S.; Kassim, K.A.; Zango, M.U. Review on biological process of soil improvement in the mitigation of liquefaction in sandy soil. Haryati, Y., Zurairahetty, M.Y.N., Syahrizal, I.I., Jamaludin, N., Abdullah, M.H., Ahmad, I.S., Ismail, D.S.A., Sirat, Q.A.S., Anuar, U.H.M., Ed.; In Proceedings of the 12th International Civil. Engineering Post Graduate Conference, Johor, Malaysia, 27-28 August 2018.

10. Wang, Z.; Zhang, N.; Cai, G.; Jin, Y.; Ding, N.; Shen, D. Review of ground improvement using microbial induced carbonate precipitation (MICP). Mar. Georesources Geotechnol. 2017, 45, 1-12, doi:10.1080/1064119x.2017.1297877.

11. Mujah, D.; Shahin, M.; Cheng, L. State-of-the-art review of bio-cementation by microbially induced calcite precipitation (MICP) for soil stabilization. Geomicrobiol. J. 2016, 34, 524-537, doi:10.1080/01490451.2016.1225866.

12. Achal, V.; Mukherjee, A. A review of microbial precipitation for sustainable construction. Constr. Build. Mater. 2015, 93, 1224-1235, doi:10.1016/j.conbuildmat.2015.04.051.

13. Osinubi, K.J.; O Eberemu, A.; Ijimdiya, T.S.; Yakubu, S.E.; Gadzama, E.W.; Sani, J.E.; Yohanna, P. Review of the use of microorganisms in geotechnical engineering applications. SN Appl. Sci. 2020, 2, 1-19, doi:10.1007/s42452-0201974-2. 
14. Khodadadi, T.H.; Kavazanjian, E.; van Paassen, L.; DeJong, J.Bio-Grout Materials: A Review, in Grouting 2017 : Grouting, Drilling, and Verification, Byle, M.J., Johnsen, L. F., Bruce, D. A., ElMohtar, C. S., Gazzarrini, P., Richards, T. D., Ed.; ICE: Washington, D.C., USA 2017. p. 1-12.

15. Ashraf, M.S.; Azahar, S.B.; Yusof, N.Z. Soil Improvement Using MICP and Biopolymers: A Review. IOP Conf. Series: Mater. Sci. Eng. 2017, 226, 012058, doi:10.1088/1757-899x/226/1/012058

16. Umar, M.; Kassim, K.A.; Chiet, K.T.P.; Tiong, K.; Chiet, P. Biological process of soil improvement in civil engineering: A review. J. Rock Mech. Geotech. Eng. 2016, 8, 767-774, doi:10.1016/j.jrmge.2016.02.004.

17. Yargicoglu, E.N.; Reddy, K. Review of biological diagnostic tools and their applications in geoenvironmental engineering. Rev. Environ. Sci. Bio/Technology 2014, 14, 161-194, doi:10.1007/s11157-014-9358-y.

18. Phillips, A.J.; Gerlach, R.; Lauchnor, E.; Mitchell, A.C.; Cunningham, A.B.; Spangler, L.H. Engineered applications of ureolytic biomineralization: a review. Biofouling 2013, 29, 715-733, doi:10.1080/08927014.2013.796550

19. Choi, S.-G.; Chang, I.; Lee, M.; Lee, J.-H.; Han, J.-T.; Kwon, T.-H. Review on geotechnical engineering properties of sands treated by microbially induced calcium carbonate precipitation (MICP) and biopolymers. Constr. Build. Mater. 2020, 246, 118415, doi:10.1016/j.conbuildmat.2020.118415

20. Sadjadi, M; Nikooee, E.; Habibagahi, G., Biological treatment of swelling soils using microbial calcite precipitation. In Unsaturated Soils: Research \& Applications, Khalili, N., Russell, A.R., Khoshghalb, A.; CRC press: Boca Raton, FL, USA, 2014; Volume 1 and 2, 917-922.

21. Montoya, B.M.; DeJong, J.T. Stress-Strain Behavior of Sands Cemented by Microbially Induced Calcite Precipitation. J. Geotech. Geoenvironmental Eng. 2015, 141, 04015019, doi:10.1061/(asce)gt.1943-5606.0001302.

22. Van Paassen, L.A.; Ghose, R.; Van Der Linden, T.J.M.; Van Der Star, W.; Van Loosdrecht, M.C.M. Quantifying Biomediated Ground Improvement by Ureolysis: Large-Scale Biogrout Experiment. J. Geotech. Geoenvironmental Eng. 2010, 136, 1721-1728, doi:10.1061/(asce)gt.1943-5606.0000382

23. Dejong, J.; Mortensen, B.M.; Martinez, B.C.; Nelson, D.C. Bio-mediated soil improvement. Ecol. Eng. 2010, 36, 197210, doi:10.1016/j.ecoleng.2008.12.029

24. Cheng, L.; Cord-Ruwisch, R. In situ soil cementation with ureolytic bacteria by surface percolation. Ecol. Eng. 2012, 42, 64-72, doi:10.1016/j.ecoleng.2012.01.013

25. Van Paassen, L.A.; Daza, C.M.; Staal, M.; Sorokin, D.Y.; Van Der Zon, W.; Van Loosdrecht, M.C.M. Potential soil reinforcement by biological denitrification. Ecol. Eng. 2010, 36, 168-175, doi:10.1016/j.ecoleng.2009.03.026.

26. Hamdan, N.; Kavazanjian, E.; Rittmann, B.E.; Karatas, I. Carbonate Mineral Precipitation for Soil Improvement Through Microbial Denitrification. Geomicrobiol. J. 2016, 34, 139-146, doi:10.1080/01490451.2016.1154117

27. Oliveira, P.J.V.; Da Costa, M.S.; Costa, J.N.P.; Nobre, M.F. Comparison of the Ability of Two Bacteria to Improve the Behavior of Sandy Soil. J. Mater. Civ. Eng. 2015, 27, 06014025, doi:10.1061/(asce)mt.1943-5533.0001138.

28. Zhang, J.L.; Wu, R.S.; Li, Y.M.; Zhong, J.Y.; Deng, X.; Liu, B.; Han, N.X.; Xing, F. Screening of bacteria for self-healing of concrete cracks and optimization of the microbial calcium precipitation process. Appl. Microbiol. Biotechnol. 2016, 100,6661-6670, doi:10.1007/s00253-016-7382-2

29. Gomez, M; Anderson, C.; DeJong, J.; Nelson, D.; Lau, X. Stimulating In Situ Soil Bacteria for Bio-Cementation of Sands. Geo-Congress 2014 Techn. Pap. 2014, 1674-1682.

30. Gomez, M.G.; Anderson, C.M.; Graddy, C.M.R.; DeJong, J.; Nelson, D.C.; Ginn, T.R. Large-Scale Comparison of Bioaugmentation and Biostimulation Approaches for Biocementation of Sands. J. Geotech. Geoenvironmental Eng. 2017, 143, 04016124, doi:10.1061/(asce)gt.1943-5606.0001640.

31. Chen, X.; Achal, V. Biostimulation of carbonate precipitation process in soil for copper immobilization. J. Hazard. Mater. 2019, 368, 705-713, doi:10.1016/j.jhazmat.2019.01.108

32. Fang, C.; Achal, V. Biostimulation of calcite precipitation process by bacterial community in improving cement stabilized rammed earth as sustainable material. Appl. Microbiol. Biotechnol. 2019, 103, 7719-7727, doi:10.1007/s00253-019-10024-9.

33. Van Paassen, L.A. Biogrout, Ground Improvement by Microbial Induced Carbonate Precipitation; Delft University of Technology: Delft, The Netherlands, 2009.

34. Al-Thawadi, S., High. Strength in-Situ Biocementation of Soil by Calcite Precipitating Locally Isolated Ureolytic Bacteria; Murdoch University: Murdoch, WA, Australia, 2008.

35. Cheng, L.; Cord-Ruwisch, R.; Shahin, M.A. Cementation of sand soil by microbially induced calcite precipitation at various degrees of saturation. Can. Geotech. J. 2013, 50, 81-90, doi:10.1139/cgj-2012-0023.

36. Liu, L.; Liu, H.; Stuedlein, A.W.; Evans, T.M.; Xiao, Y. Strength, stiffness, and microstructure characteristics of biocemented calcareous sand. Can. Geotech. J. 2019, 56, 1502-1513, doi:10.1139/cgj-2018-0007

37. Ahenkorah, I.M.M.; Rahman, M.R.; Karim, P.R. Teasdale, A comparison of mechanical responses for Microbial and Enzyme-induced cemented Sand. Géotechn. Lett. 2020. (In Press)

38. Cheng, L.; Cord-Ruwisch, R. Upscaling Effects of Soil Improvement by Microbially Induced Calcite Precipitation by Surface Percolation. Geomicrobiol. J. 2014, 31, 396-406, doi:10.1080/01490451.2013.836579 
39. Nafisi, A; Mocelin, D.; Montoya, B.M.; Underwood, S.; Tensile strength of microbially induced carbonate precipitation treated sands. Canad. Geotech. J. 2019.

40. Choi, S.-G.; Hoang, T.; Alleman, E.J.; Chu, J. Splitting Tensile Strength of Fiber-Reinforced and Biocemented Sand. J. Mater. Civ. Eng. 2019, 31, 06019007, doi:10.1061/(asce)mt.1943-5533.0002841

41. Choi, S.-G.; Wang, K.; Chu, J. Properties of biocemented, fiber reinforced sand. Constr. Build. Mater. 2016, 120, 623629, doi:10.1016/j.conbuildmat.2016.05.124

42. Xiao, Y.; He, X.; Evans, T.M.; Stuedlein, A.W.; Liu, H. Unconfined Compressive and Splitting Tensile Strength of Basalt Fiber-Reinforced Biocemented Sand. J. Geotech. Geoenvironmental Eng. 2019, 145, 04019048, doi:10.1061/(asce)gt.1943-5606.0002108

43. Hang, L.; Gao, Y.F.; He, J.; Chu, J. Mechanical behaviour of biocemented sand under triaxial consolidated undrained or constant shear drained conditions. Geomech. Eng. 2019, 17, 497-505.

44. Riveros, G.A.; Sadrekarimi, A. Liquefaction resistance of Fraser River sand improved by a microbially-induced cementation. Soil Dyn. Earthq. Eng. 2020, 131, 106034, doi:10.1016/j.soildyn.2020.106034.

45. Ozdogan, A. A Study on the Triaxial Shear Behavior and Microstructure of Biologically Treated Sand Specimens. In Department of Civil. and Environmental Engineering; University of Delaware: Newark, DE, USA, 2010.

46. Nafisi, A.; Montoya, B.M.; Evans, T.M. Shear Strength Envelopes of Biocemented Sands with Varying Particle Size and Cementation Level. J. Geotech. Geoenvironmental Eng. 2020, 146, 04020002, doi:10.1061/(asce)gt.19435606.0002201

47. Arboleda-Monsalve, L.G.; Zapata-Medina, D.G.; Galeano-Parra, D.I. Compressibility of biocemented loose sands under constant rate of strain, loading, and pseudo K-triaxial conditions. Soils Found. 2019, 59, 1440-1455, doi:10.1016/j.sandf.2019.06.008

48. Feng, K.; Montoya, B.M. Drained Shear Strength of MICP Sand at Varying Cementation Levels. IFCEE 20152015, 2242-2251, doi:10.1061/9780784479087.208.

49. Nafisi, A.; Safavizadeh, S.; Montoya, B.M. Influence of Microbe and Enzyme-Induced Treatments on Cemented Sand Shear Response. J. Geotech. Geoenvironmental Eng. 2019, 145, 06019008, doi:10.1061/(asce)gt.19435606.0002111

50. Xiao, P.; Liu, H.; Stuedlein, A.W.; Evans, T.M.; Xiao, Y. Effect of relative density and biocementation on cyclic response of calcareous sand. Can. Geotech. J. 2019, 56, 1849-1862, doi:10.1139/cgj-2018-0573.

51. Terzis, D.; Laloui, L. Cell-free soil bio-cementation with strength, dilatancy and fabric characterization. Acta Geotech. 2019, 14, 639-656, doi:10.1007/s11440-019-00764-3.

52. Burbank, M.; Weaver, T.; Green, T.L.; Williams, B.C.; Crawford, R. Precipitation of Calcite by Indigenous Microorganisms to Strengthen Liquefiable Soils. Geomicrobiol. J. 2011, 28, 301-312, doi:10.1080/01490451.2010.499929

53. Mahawish, A.; Bouazza, A.; Gates, W.P. Unconfined Compressive Strength and Visualization of the Microstructure of Coarse Sand Subjected to Different Biocementation Levels. J. Geotech. Geoenvironmental Eng. 2019, 145, 04019033, doi:10.1061/(asce)gt.1943-5606.0002066

54. Hoang, T.; Alleman, J.; Cetin, B.; Choi, S.-G. Engineering Properties of Biocementation Coarse- and Fine-Grained Sand Catalyzed By Bacterial Cells and Bacterial Enzyme. J. Mater. Civ. Eng. 2020, 32, 04020030, doi:10.1061/(asce)mt.1943-5533.0003083.

55. Danjo, T.; Kawasaki, S. Microbially Induced Sand Cementation Method Using Pararhodobacter sp. Strain SO1, Inspired by Beachrock Formation Mechanism. Mater. Trans. 2016, 57, 428-437, doi:10.2320/matertrans.mm2015842.

56. Choi, S.G.; Chu, J.; Brown, R.C.; Wang, K.; Wen, Z. Sustainable Biocement Production via Microbially Induced Calcium Carbonate Precipitation: Use of Limestone and Acetic Acid Derived from Pyrolysis of Lignocellulosic Biomass. ACS Sustain. Chem. Eng. 2017, 5, 5183-5190, doi:10.1021/acssuschemeng.7b00521

57. Amarakoon, G.G.N.N.; Kawasaki, S. Factors affecting sand solidi cation using micp with pararhodobacter sp. Mater. Transac. 2017, 1-10.

58. Cheng, L.; Shahin, M.A.; Mujah, D. Influence of Key Environmental Conditions on Microbially Induced Cementation for Soil Stabilization. J. Geotech. Geoenvironmental Eng. 2017, 143, 04016083, doi:10.1061/(asce)gt.19435606.0001586

59. Choi, S.-G.; Wu, S.; Chu, J. Biocementation for Sand Using an Eggshell as Calcium Source. J. Geotech. Geoenvironmental Eng. 2016, 142, 06016010, doi:10.1061/(asce)gt.1943-5606.0001534.

60. Gomez, M.G.; DeJong, J.; Byle, M.J.; Johnsen, L.F.; Bruce, D.A.; El Mohtar, C.S.; Gazzarrini, P.; Richards, T.D. Engineering Properties of Bio-Cementation Improved Sandy Soils. Grouting 2017 2017, 23-33.

61. Li, M.; Wen, K.; Li, Y.; Zhu, L. Impact of oxygen availability on microbially induced calcite precipitation (MICP) treatment. Geomicrobiol. J. 2017, 34, 15-22, doi:10.1080/01490451.2017.1303553.

62. Soon, N.W.; Lee, M.L.; Khun, T.C.; Ling, H.S. Factors Affecting Improvement in Engineering Properties of Residual Soil 
through Microbial-Induced Calcite Precipitation. J. Geotech. Geoenvironmental Eng. 2014, 140, 04014006, doi:10.1061/(asce)gt.1943-5606.0001089..

63. Cui, M.-J.; Zheng, J.-J.; Zhang, R.-J.; Lai, H.-J.; Zhang, J. Influence of cementation level on the strength behaviour of bio-cemented sand. Acta Geotech. 2017, 12, 971-986, doi:10.1007/s11440-017-0574-9.

64. Qabany, A.; Soga, K. Effect of chemical treatment used in MICP on engineering properties of cemented soils. Géotechnique 2013, 63, 331-339, doi:10.1680/geot.sip13.p.022

65. Le Métayer-Levrel, G.; Castanier, S.; Orial, G.; Loubière, J.-F.; Perthuisot, J.-P. Applications of bacterial carbonatogenesis to the protection and regeneration of limestones in buildings and historic patrimony. Sediment. Geol. 1999, 126, 25-34, doi:10.1016/s0037-0738(99)00029-9

66. Webster, A.; May, E. Bioremediation of weathered-building stone surfaces. Trends Biotechnol. 2006, 24, 255-260, doi:10.1016/j.tibtech.2006.04.005

67. Ivanov, V.; Chu, J. Applications of microorganisms to geotechnical engineering for bioclogging and biocementation of soil in situ. Rev. Environ. Sci. Bio/Technology 2008, 7, 139-153, doi:10.1007/s11157-007-9126-3.

68. Ramachandran, S.K; Ramakrishnan, V.; Bang, S.S.; Remediation of concrete using micro-organisms. ACl Mater. J. A. Conc. Inst. 2001, 98, 3-9.

69. Jonkers, H.M.; Thijssen, A.; Muyzer, G.; Çopuroğlu, O.; Schlangen, E. Application of bacteria as self-healing agent for the development of sustainable concrete. Ecol. Eng. 2010, 36, 230-235, doi:10.1016/j.ecoleng.2008.12.036

70. Achal, V.; Mukherjee, A.; Reddy, M.S. Microbial Concrete: Way to Enhance the Durability of Building Structures. J. Mater. Civ. Eng. 2011, 23, 730-734, doi:10.1061/(asce)mt.1943-5533.0000159

71. Amidi, S.; Wang, J. Surface treatment of concrete bricks using calcium carbonate precipitation. Constr. Build. Mater. 2015, 80, 273-278, doi:10.1016/j.conbuildmat.2015.02.001.

72. Abo-El-Enein, S.; Ali, A.; Talkhan, F.N.; Abdel-Gawwad, H. Utilization of microbial induced calcite precipitation for sand consolidation and mortar crack remediation. HBRC J. 2012, 8, 185-192, doi:10.1016/j.hbrcj.2013.02.001.

73. Cheng, L.; Shahin, M.; Cord-Ruwisch, R. Bio-cementation of sandy soil using microbially induced carbonate precipitation for marine environments. Géotechnique 2014, 64, 1010-1013, doi:10.1680/geot.14.t.025.

74. Sarda, D.; Choonia, H.S.; Sarode, D.D.; Lele, S. Biocalcification by Bacillus pasteurii urease: a novel application. J. Ind. Microbiol. Biotechnol. 2009, 36, 1111-1115, doi:10.1007/s10295-009-0581-4

75. Raut, S.H.; Sarode, D.D.; Lele, S.S. Biocalcification using B. pasteurii for strengthening brick masonry civil engineering structures. World J. Microbiol. Biotechnol. 2013, 30, 191-200, doi:10.1007/s11274-013-1439-5

76. Lambert, S.; Randall, D. Manufacturing bio-bricks using microbial induced calcium carbonate precipitation and human urine. Water Res. 2019, 160, 158-166, doi:10.1016/j.watres.2019.05.069.

77. Fu, F.; Wang, Q. Removal of heavy metal ions from wastewaters: A review. J. Environ. Manag. 2011, 92, 407-418, doi:10.1016/j.jenvman.2010.11.011

78. Fujita, Y.; Ferris, F.; Lawson, R.; Colwell, F.; Smith, R. Subscribed Content Calcium Carbonate Precipitation by Ureolytic Subsurface Bacteria. Geomicrobiol. J. 2000, 17, 305-318, doi:10.1080/782198884

79. Cunningham, A.; Gerlach, R.; Spangler, L.; Mitchell, A. Microbially enhanced geologic containment of sequestered supercritical CO2. Energy Procedia 2009, 1, 3245-3252, doi:10.1016/j.egypro.2009.02.109

\section{Keywords}

sustainable construction; Microbial-Induced Calcite Precipitation; Biocementation; biostimulation; bioaugmentation; biological process; sustainable; cementation; ground improvement; calcium carbonate

(c) 2020 by the author(s). Distribute under a Creative Commans CC BY license 